\title{
PENERAPAN TECHNOLOGY ACCEPTANCE MODEL (TAM) DALAM PENGUJIAN MODEL PENERIMAAN SISTEM INFORMASI KEUANGAN DAERAH
}

\author{
Fran Sayekti \& Pulasna Putarta \\ Universitas Teknologi Yogyakarta
}

E-mail: fsayekti@yahoo.com \& putarta04@gmail.com

\begin{abstract}
This study analyzed the factors which influence the acceptance of the Financial Information System for local Government (SIPKD) using the Technology Acceptance Model (TAM). TAM stated that behavioral intension to use Information System are determined by two beliefs: perceived usefulness (POU) and perceived ease of use (PEU). Perceived usefulness (POU) was defined as the extent to people were sure that the use of the system will improve its performance. Perceived ease of use (PEU) was defined as the extent to people were sure that the system is easy to use. This study analyzed the acceptance SIPKD in the context of the acceptance by the user. User are the local government employee have an obligation to run SIPKD. The analysis focused on the user's perception regarding SIPKD they should run. User perception analyzed is user perception about the ease of use SIPKD and user perceptions about the benefits SIPKD in their work. Research was conducted on the SIPKD in the Special Province of Yogyakarta. Respondents of this study 67 from various agencies in the region of Yogyakarta. The results showed that the Perceived usefulness influence the using of SIPKD, while Perceived Ease of Use does not influence
\end{abstract}

Keywords: Technology Acceptance Model, behavioral intension to use, Perceived Usefulness, Perceived Ease of Use. 
Munculnya paradigma baru New Public Management merupakan kerangka reformasi birokrasi menuju ke pemerintahan yang baik (Good Governance) di Indonesia. Paradigma tersebut mendasari adanya tuntutan good governance yang dewasa ini telah menjadi kata kunci dalam setiap perumusan tujuan kebijakan reformasi birokrasi pemerintahan dalam kerangka perubahan dan pendayagunaan sistem administrasi negara dalam arti yang seluas-luasnya di Indonesia (Fernanda, 2011). New Public Management mendorong adanya usaha untuk meningkatkan kinerja dibidang pengelolaan keuangan di pemerintahan Indonesia dengan mengembangkan pendekatan yang lebih sistematis dalam pengelolaan keuangan pemerintah dengan tiga prinsip good governance daerah yang menurut Gambhir Bhatta (1996) bercirikan tingginya tingkat akuntabilitas (accountability), transparansi (transparency), keterbukaan (openness), dan supremasi hukum (rule of law).

Pemerintah menerbitkan Peraturan Pemerintah No. 56 Tahun 2005 tentang Sistem Informasi Keuangan Daerah dan Peraturan Menteri Keuangan No. 46 Tahun 2006 tentang Tata Cara Penyampaian Informasi Keuangan Daerah, selanjutnya dijabarkan dengan Surat Edaran No. SE.900/122/BAKD tentang basis dan pengembangan dan Koordinasi Sistem Informasi Pengelolaan Keuangan Daerah ( SIPKD ). Peraturan tersebut bertujuan membantu Pemerintah Daerah dalam menyusun laporan Pertanggungjawaban Pengelolaan Keuangan Daerah. Pemerintah Daerah wajib menyampaikan data/informasi yang berkaitan dengan keuangan daerah kepada Pemerintah Pusat . Penyampaian Data/informasi tersebut disampaikan melalui Sistem Informasi Pengelolaan Keuangan Daerah ( SIPKD). SIPKD dikembangkan dengan basis teknologi informasi yang didesain sedemikian rupa agar menjadi sarana pengumpulan, pengolahan, penyajian, dan referensi, serta proses komunikasi data/informasi keuangan daerah antara Departemen Keuangan dan Departemen Dalam Negaeri dengan Pemerintah Daerah dan para pemilik atau pengguna informasi keuangan daerah lainnya.

Peraturan Pemerintah No. 56 Tahun 2005 dan Peraturan Menteri Keuangan No. 46 Tahun 2006 menyatakan kewajiban bagi pengelola keuangan di tiap SKPD untuk menggunakan Sistem Informasi Kevangan Daerah (SIPKD). Setiap pengelola kevangan tiap SKPD wajib memahami SIPKD dengan baik agar proses penatausahaan keuangan daerah tidak terhambat. Penelitian ini akan menganalisis faktor-faktor yang mempengaruhi penerimaan SIPKD di lingkungan Pemerintah Provinsi Daerah Istimewa Yogyakarta. Analisis berdasarkan pada Theory Acceptance Model (TAM).

TAM mendasarkan diri pada Theory of Reasoned Action (TRA) yang dikemukakan Ajzen dan Fisbein (1980). TRA menjelaskan adanya reaksi dan persepsi pengguna Teknologi Informasi (TI) yang pada akhirnya akan mempengaruhi sikapnya dalam penerimaan terhadap teknologi tersebut. Tujuan utama TAM adalah memberikan penjelasan tentang penentuan penerimaan komputer secara umum, memberikan penjelasan tentang perilaku atau sikap pengguna dalam suatu populasi (Davis et.al., 1989). TAM menyatakan bahwa behavioral intension to use ditentukan oleh dua keyakinan yaitu: pertama, perceived usefulness yang didefinisikan sebagai sejauh mana seseorang yakin bahwa menggunakan sistem akan meningkatkan kinerjanya. Kedua, perceived ease of use yang didefinisikan sebagai sejauh mana seseorang yakin bahwa penggunaan sistem adalah mudah. TAM juga menyatakan bahwa dampak variabel-variabel eksternal seperti (karakteristik sistem, proses pengembangan dan pelatihan) terhadap intension to use adalah dimediasi oleh perceived of usefulness dan perceived ease of use. Konsep TAM juga menyatakan bahwa perceived usefulness dipengaruhi oleh perceived ease of used. Venkatesh dan Davis (2000) menyatakan bahwa TAM merupakan sebuah konsep yang dianggap paling baik dalam 
menjelaskan perilaku user terhadap sistem teknologi informasi baru. TAM merupakan model yang dianggap paling tepat dalam menjelaskan bagaimana user menerima sebuah sistem.

Pemakaian TAM dalam penelitian tentang penerimaan penerapan teknologi sudah dilakukan oleh beberapa peneliti di negara yang berbeda dan penerapan teknologi yang berbeda pula untuk menguji keakuratan TAM (Tangke, 2004). Hambali dkk (2011) melakukan penelitian tentang penerimaan nasabah terhadap internet banking dengan pendekatan TAM dan menambahkan variabel personalization, computer self efisiensy, dan kepercayaan (trust). Hasil penelitiannya menunjukkan bahwa personalisasi (personalization), kemampuan terhadap komputer (computer self efisiensy) dan kepercayaan mempunyai pengaruh yang positif terhadap perceived usefulness karena nasabah akan menilai bahwa internet banking bermanfaat apabila mereka memiliki kemampuan menggunakan komputer,personalisasi atau keinginan dan kepercayaan menggunakan internet banking.

Penelitian ini berusaha untuk menganalisis faktor-faktor yang mempengaruhi penerimaan SIPKD oleh pengguna SIPKD di lingkungan Pemerintah Kota Yogyakarta.dengan pendekatan TAM (Technology Acceptance Model). Penelitian ini penting dilakukan mengingat SIPKD meruapakan sistem penatausahaan transaksi keuangan di Lembaga Pemerintahan. Dengan diketahuinya faktor-faktor yang mempengaruhi penerimaan SIPKD maka akan mudah bagi pihak Pemkot untuk melakukan proses sosialisasi dan pelatihan untuk penggunaan SIPKD. Penelitian dengan kondisi ini sesuai dengan pernyataan Compeau dan Higgins (1995) yang menyatakan bahwa tahapan kritis dalam penerapan sebuah sistem teknologi informasi adalah kondisi dimana kehadiran sistem tersebut diterima atau ditolak oleh calon user. Terhambatnya proses adaptasi ini terjadi karena adanya kecenderungan perbedaan persepsi mengenai manfaat dan kemudahan sistem baru untuk dioperasikan.

Tujuan penelitian ini untuk mengetahui apakah dari sisi user penggunaan SIPKD dapat diterima sebagai suatu sistem yang meningkatkan kinerja, bukan sekedar kewajiban yang harus dijalani.

\section{Landasan Teori dan Pengembangan Hipotesis}

Sistem informasi dalam suatu instansi, berfungsi sebagai alat bantu pencapaian tujuan melalui penyediaan informasi. Keberhasilan sistem informasi sebagai pencapaian alat bantu pencapaian tujuan melalui penyediaan informasi. Keberhasilan sistem informasi tidak hanya ditentukan oleh bagaimana sistem tersebut dapat memproses masukan dan menghasilkan informasi dengan baik, tetapi ditentukan juga oleh kesesuaiannya dengan lingkungan pekerjaan karena walaupun sistem informasi tersebut menggunakan teknologi canggih, sistem belum bisa dikatakan berhasil bila pemakai sistem informasi tidak dapat menerimanya atau bahkan enggan menggunakannya (Jogiyanto, 2005). Kesuksesan sistem informasi dapat diukur dengan empat jenis ukuran, yaitu kepuasan pemakai, penggunaan sistem, kinerja keputusan, dan kinerja organisasi. Dalam penelitian ini kepuasan pemakai dan penggunaan sistem informasi digunakan untuk mengukur kesuksesan sistem informasi, seperti yang dilakukan oleh Hartwick (1994). Pemanfaatan teknologi atau sistem informasi menunjukkan keputusan individu untuk menggunakan atau tidak menggunakan teknologi atau sistem informasi dalam menyelesaikan serangkaian tugas (Goodhue, 1995).

Salah satu unsur penting dalam penerapan sebuah sistem informasi adalah penerimaan terhadap sistem informasi tersebut. Bagi sebuah organisasi, sistem informasi berfungsi sebagai alat bantu untuk pencapaian tujuan organisasi melalui penyediaan informasi. Kesuksesan sebuah sistem informasi tidak hanya ditentukan oleh bagaimana sistem dapat memproses 
masukan dan menghasilkan informasi dengan baik, tetapi juga bagaimana pengguna mau menerima dan menggunakannya, sehingga mampu mencapai tujuan organisasi.

Penerimaan terhadap sistem informasi dapat diukur dengan beberapa model evaluasi yang sudah dikembangkan saat ini. Ada banyak model evaluasi yang digunakan untuk mengukur penerimaan sebuah sistem informasi yang digunakan oleh sebuah organisasi atau institusi publik. model evaluasi yang sering digunakan untuk mengukur penerimaan sistem informasi (Wilkinson,2000) adalah: End User Computing Satisfaction, Task Technology Fit, HumanOrganization-Technology (HOT) dan Technology Acceptance Model (TAM). Technology Accpetance Model ini yang akan digunakan untuk menguji penerimaan SIPKD di lingkungan instansi pemerintah daerah.

Technology acceptance model (TAM) ini diformulakan oleh Ajzend an Fishben (1980). Teori tersebut merupakan hasil dari penelitian mereka pada tahun 1980. Teori ini menjelaskan bahwa seseorang dalam melakukan sesuatu didorong oleh dua faktor yaitu behavior beliefs dan Normatif beliefs. Faktor tersebut kemudian mendorong seseorang untuk memiliki outcome evaluation dan motivation to comply. Sehingga kedua hal tersebut akan mendorong seseorang untuk berperilaku (Attitude) dan Norma-Norma Pribadi ( Subjective Norms). Adanya Attitude dan Subjective Norms akan mempengaruhi perhatian/fokus seseorang dalam berberilaku (behavior intention). Pada akhir Behavior Intention akan mempengaruhi pada perilaku seseorang (behavior).

Davis et.al. (1989) mengembangkan TAM untuk meneliti faktor-faktor determinan dari penggunaan sistem informasi oleh pengguna. Hasil penelitian ini menunjukan penggunaan sistem informasi dipengaruhi oleh minat (Intention) pemanfaatan sistem informasi, yang mana minat (Intention) tersebut dipengaruhi oleh persepsi tentang kegunaan teknologi (perceived usefulness) dan persepsi tentang kemudahan penggunaan teknologi (perceived ease of use).

Penelitian I Putu Sugiartha Sanjaya (2005) tentang Pengaruh Rasa Manfaat dan Kemudahan Terhadap Minat Berperilaku (Behavioral Intention) Para Mahasiswa dalam Menggunakan Internet. Hasil penelitiannya menunjukkan bahwa manfaat (Perceived Usefulness) dapat mempengaruhi seseorang dalam menggunakan internet, sedangkan kemudahaan (Perceived Ease of Use) tidak dapat mempengaruhi sesorang dalam menggunakan internet.

Penelitian Kartika (2009) tentang Analisis Proses Penerimaan Sistem Informasi iCons Dengan Menggunakan Technology Acceptance Model pada Karyawan PT.Bank Negara Indonesia (Persero) Tbk. Di Kota Semarang. Hasil Penelitiannya menunjukkan Self-Efficacy mempunyai hubungan yang positif dengan perceived usefullnes dalam penggunaan sistem informasi iCons. Hal ini mengindikasikan bahwa tinggi rendahnya kemampuan karyawan untuk mengambil tindakan berdampak pada persepsi manfaat dari pemanfaatan sistem iCons.

Penelitian yang dilakukan Muntianah dkk (2012) yang menganalisis TAM terhadap perilaku penggunaan sistem informasi pada kegiatan belajar mahasiswa di Fakultas IImu Administrasi Brawijaya menyebutkan bahwa persepsi kemudahan penggunaan TI berpengaruh pada persepsi kemanfaatan, dalam arti apabila pengguna TI merasa mudah menggunakan TI nya maka dia juga akan berpendapat bahwa TI itu bermanfaat. Sedangkan persepsi kemanfaatan berpengaruh terhadap minat menggunakan $\mathrm{Tl}$, yang berarti apabila 
pengguna TI merasa TI bermanfaat maka pengguna berminat menggunakan TI. Dan hasil berikutnya adalah Minat menggunakan TI mempengaruhi penggunaan TI sesungguhnya. Dengan kata lain apabila pengguna TI berminat menggunakan TI maka pengguna itu akan benar-benar merealisasikan dengan sesungguhnya menggunakan TI.

Berdasarkan uraian teori dan hasil penelitian terdahulu, maka dapat dirumuskan hipotesis:

1. Apabila pemakai SIPKD mempunyai persepsi bahwa SIPKD tersebut mudah digunakan dan memudahkan pekerjaan mereka maka mereka akan semakin sering menggunakan SIPKD untuk menyelesaikan pekerjaan mereka, sehingga hipotesis yang diajukan adalah:

H1: Faktor kemudahan (Perceived Ease of Use) berpengaruh positif terhadap penerimaan SIPKD

2. Apabila pemakai SIPKD mempunyai persepsi bahwa SIPKD berguna dalam penyelesaian pekerjaan mereka, maka pemakai akan semakin sering menggunakan SIPKD dalam pekerjaan mereka. Sehingga hipotesis kedua yang diajukan dalam penelitian ini adalah

H2: Faktor kegunaan (Perceived Usefulness) berpengaruh positif terhadap penerimaan SIPKD

3. Apabila pemakai mempunya persepsi bahwa SIPKD mudah digunakan dan bermanfaat dalam menyelesaikan pekerjaan mereka, maka pemakai akan semakin sering menggunakan SIPKD dalam pekerjaan mereka. Sehingga hipotesis ketiga yang diajukan dalam penelitian ini adalah:

H3: Faktor kemudahan (Perceived Ease of Use) dan faktor kegunaan (Perceived Usefulness) secara bersama-sama berpengaruh positif terhadap penerimaan SIPKD.

\section{Metode Penelitian}

Metode penelitian yang digunakan dalam penelitian adalah metode kuantitatif, yaitu menggambarkan kondisi yang diteliti menggunakan angka dan pengambilan keputusan atas hasil penelitian berdasarkan pada angka-angka statistik. Pada penelitian ini terdapat tiga buah variabel yang terbagi ke dalam dua jenis variabel. Yang pertama adalah variabel bebas. Variabel bebas dalam penelitian ini adalah kegunaan teknologi (perceived usefulness) dan kemudahan menggunakan teknologi (perceived ease of use). Varibel yang kedua adalah variabel dependen atau variabel terikat. Dalam penelitian ini variabel terikatnya adalah variabel penerimaan teknologi dalam hal ini penerimaan SIPKD.

Perceived ease of use menggambarkan bagaimana persepsi pengguna SIPKD terhadap kemudahan penggunaan SIPKD. Indikator yang dipakai untuk mengukur variabel persepsi kemudahan penggunaan SIPKD adalah kemudahan untuk dipelajari (easy to learn), kemudahan mencapai tujuan (controllable), jelas dan mudah dipahami (clear and understabel), fleksibel (flexible), bebas dari kesulitan (easy become skillfull), dan kemudahan penggunaan (easy to use) (Davis, 1989).

Variabel Persepsi Kegunaan Teknologi mengukur bagaimana persepsi responden terhadap kegunaan SIPKD dalam pekerjaan mereka. Variabel ini diukur dengan menanyakan indikator-indikator sebagai berikut: produktivitas (productivity), kinerja tugas atau efektivitas (job performance/ effectiveness), pentingnya bagi tugas (important to job), dan kegunaan secara keseluruhan (overall usefulness). 
Variabel penerimaaan SIPKD (intention to use) ini diukur dengan menggunakan indokator keinginan untuk tetap menggunakan di masa yang akan datang. Artinya disini akan dilihat sejauh mana pengguna mau menggunakan sistem informasi dalam pekerjaan sehari-hari dan tugas-tugasnya.

Jawaban responden dalam penelitian ini hasil akan diukur dengan skala likert dengan interval: 1 = Sangat Tidak Setuju; 2 = Tidak Setuju; 3 = Netral; 4 = Setuju; 5 = Sangat Setuju .

Dari variabel penelitian tersebut, dapat digambarkan model dan skema penelitian sebagai berikut:

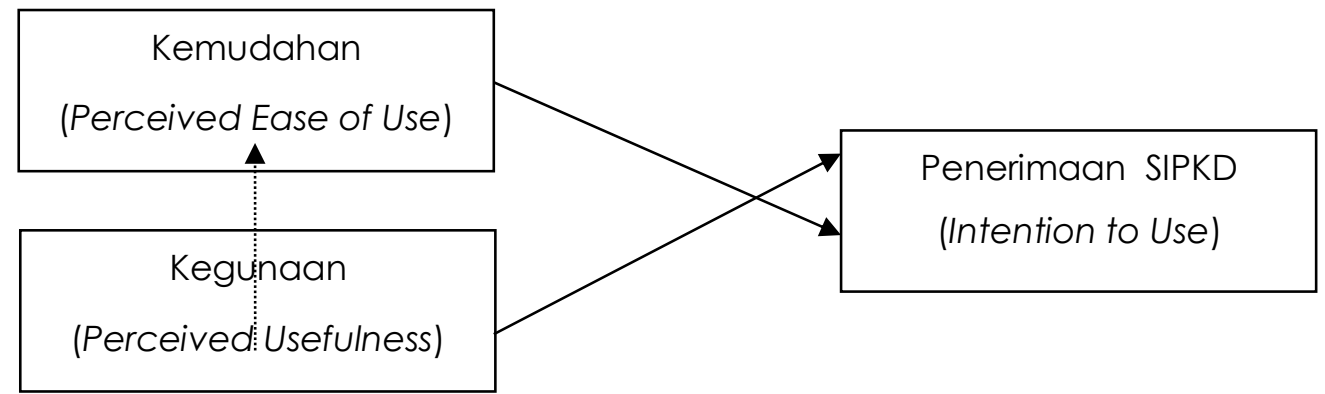

Gambar 1 Model dan skema penelitian/analisis penerimaan SIPKD

Metode analisis data

Data dalam penelitian diperoleh dengan menyebarkan kuesioner pada user/operator SIPKD pada lembaga pemerintah di Wilayah Daerah Istimewa Yogyakarta. Jumlah kuesioner yang disebar sebanyak 100 kuesioner, jumlah kuesioner kembali sebanyak 73 kuesioner (responrate 73\%). Kuesioner yang lengkap dan dapat diproses sebanyak 67 kuesioner (useable rate 67\%). Analisis data melalui dua tahap, yaitu uji kualitas data berupa uji validitas dan uji reliabilitas. Uji validitas menggunakan korelasi spearman, yaitu dengan mengkorelasikan nilai tiap butir pernyataan dengan nilai totalnya, dengan standar koefisien korelasi diatas 0,5. Apabila koefisien korelasi nilai 0,5 atau lebih, maka data dainyatakan valid. Hasil Uji validitas disajikan dalam tabel berikut ini:

Tabel 1

Hasil Uji Kualitas Data

\begin{tabular}{|l|l|l|}
\hline Butir Pertanyaan & $\begin{array}{l}\text { Koefisien korelasi } \\
\text { dgn total nilai }\end{array}$ & keterangan \\
\hline PEU No. 1 &, $862^{* *}$ & valid \\
\hline PEU No. 2 &, $838^{* *}$ & valid \\
\hline PEU No. 3 &, $911^{* *}$ & valid \\
\hline PEU No. 4 &, $876^{* *}$ & valid \\
\hline
\end{tabular}




\begin{tabular}{|l|l|l|}
\hline PEU No. 5 &, $753^{* *}$ & valid \\
\hline PEU No. 6 &, $789^{* *}$ & valid \\
\hline PEU No. 7 &, $928^{* *}$ & valid \\
\hline POU No. 1 &, $916^{* *}$ & valid \\
\hline POU No. 2 &, $950^{* *}$ & valid \\
\hline POU No. 3 &, $962^{* *}$ & valid \\
\hline POU No. 4 &, $965^{* *}$ & valid \\
\hline POU No. 5 &, $946^{* *}$ & valid \\
\hline POU No. 6 &, $725^{* *}$ & valid \\
\hline Penerimaan No. 1 &, $770^{* *}$ & valid \\
\hline Penerimaan No. 2 &, $645^{* *}$ & valid \\
\hline Penerimaan No. 3 &, $788^{* *}$ & valid \\
\hline
\end{tabular}

Berdasarkan tabel 1 dapat diketahui bahwa semua elemen pernyataan dalam variabel penelitian dinyatakan valid

Sedangkan uji reliabilitas menggunakan cronbach alpha, dengan standar 0,6. Apabila nilai cronbach alpha diatas $p, 6$ maka pernyataan dalam kuesioner dinyatakan reliabel. Untuk uji hipotesis digunakan regresi berganda.

Hasil Uji Reliabilitas disajikan dalam tabel berikut ini:

Tabel 2

Hasil Uji Reliablitas

\begin{tabular}{|l|l|l|}
\hline Butir Pertanyaan & $\begin{array}{l}\text { Nilai Cronbach } \\
\text { Alpha }\end{array}$ & Keterangan \\
\hline Perceived ease of use (PEU) &, 928 & Reliabel \\
\hline Perceived of usefullness (POU) &, 959 & Reliabel \\
\hline Penerimaan &, 764 & Reliabel \\
\hline
\end{tabular}

Berdasarkan hasil uji reliabilitas yang ada di tabel 2, maka dapat dikatakan bahwa data dalam penelitian ini semuanya reliable karena nilai cronbach alph diatas 0,6 .

Hipotesis dalam penelitian ini diuji dengan regresi berganda. Analisis ini digunakan untuk melihat pengaruh dari sejumlah variabel independen terhadap variabel dependen yang masing-masing memiliki skala rasio/interval (Jakaria, 2005)

Persamaan regresi berganda dalam penelitian ini adalah:

$Y=a+\beta 1 X 1+\beta 2 X 2+€$

$Y=$ Penerimaan SIPKD (Intention to Use)

$\mathrm{X} 1=$ Persepsi Kemudahan Penggunaan (Perceived Ease of Use) 


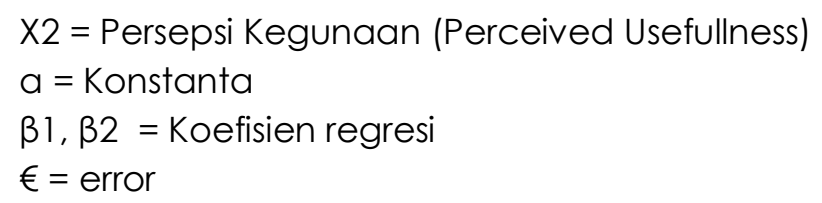

Analisis regresi berganda yang dilakukan terdiri dari pengujian model, uji $F$ (Uji serentak) dan uji- $\dagger$ (uji individu). Pengujian model dilakukan dengan melihat hasil pengolahan regresi berganda yaitu pada koefisien determinasi $R^{2}$ (Goodness of Fit Model). Uji ini diperlukan untuk mengetahui sejauh mana variasi variabel independen yang dipakai dalam penelitian mampu menjelaskan variasi dari variabel dependen. Uji $F$ (uji serentak) dilakukan untuk menguji apakah variabel independen secara bersama-sama mempunyai pengaruh yang signifikan terhadap variabel dependen. Artinya apakah dalam penelitian ini akan terbukti bahwa variabel kegunaan dan variabel kemudahan secara keseluruhan bersama-sama mempunyai pengaruh yang signifikan terhadap variabel penerimaan sistem (Behavior Intention to Use). Uji † (uji individu) dilakukan untuk menguji pengaruh dari masing-masing variabel independen terhadap variabel dependen. Artinya pada uji t ini akan dilakukan pengujian pengaruh variabel kegunaan terhadap variabel penerimaan dan pengaruh variabel kemudahan terhadap variabel penerimaan.

\section{Pembahasan dan Kesimpulan}

Penelitian ini melibatkan 67 responden dari instansi di wilayah Provinsi daerah Istimewa Yogyakarta. Berikut ini dijelaskan karakteristik responden dalam penelitian ini:

Usia responden yang terlibat dalam penelitian ini tercantum dalam tabel 5.2. berikut ini:

Tabel 3.

Usia Responden

\begin{tabular}{|l|c|c|c|}
\hline & Jumlah & $\begin{array}{c}\text { Persentas } \\
\text { e }\end{array}$ & $\begin{array}{c}\text { Kumulatif } \\
\text { Persentase }\end{array}$ \\
\hline dibawah 30 thn & 4 & 6,3 & 6,3 \\
antara 30 - 40 thn & 15 & 23,4 & 29,7 \\
antara 40 - 50 thn & 38 & 59,4 & 89,1 \\
diatas 50 thn & 7 & 10,9 & 100,0 \\
Total & 64 & 100,0 & \\
\hline
\end{tabular}

Berdasarkan tabel 5.2 tersebut dapat diketahui bahwa responden yang berpartisipasi dalam penelitian ini terbanyak berusia 40 - 50 tahun yaitu sekitar 38 orang atau 59,4\% dari jumlah total responden. Hal ini mengindikasikan bahwa yang mengisi kueisoner memang karyawan yang berada dalam usia produktif matang, yaitu produktif yang sudah diakhir masa produktivitas. Dan apabila dicermati, pengguna SIPKD memang tidak bisa sembarang karyawan. Hanya karyawan dengan kualifikasi tertentu yang diberi kewenangan untuk menggunakan SIPKD. 
Tingkat pendidikan responden yang terlibat dalam penelitian ini disajikan dalam tabel 4 berikut ini:

Tabel 4.

Tingkat Pendidikan Responden

\begin{tabular}{|l|r|r|r|}
\hline & Jumlah & Persentase & $\begin{array}{c}\text { Kumulatif } \\
\text { Persentase }\end{array}$ \\
\hline diploma & 6 & 9,4 & 9,4 \\
sarjana strata 1 & 40 & 62,5 & 71,9 \\
sarjana strata 2 & 2 & 3,1 & 75,0 \\
lainnya & 16 & 25,0 & 100,0 \\
Total & 64 & 100,0 & \\
\hline
\end{tabular}

Tingkat pendidikan responden yang terbanyak dalam penelitian ini adalah sarjana strata 1. Tingkat pendidikan mengindikasikan tingkat pemahaman responden atas kuesioner yang diisi. Dengan tingkat pendidikan sarjana, maka dapat diasumsikan bahwa responden adalah orang yang memahami pertanyaan dalam kuesioner, sehingga diharapkan hasilnya tidak bias.

Responden yang terlibat dalam penelitian ini berasal dari berbagai instansi yang ada di DIY, baik instansi di wilayah tingkat Il (kabupaten dan Kota) maupun instansi di PEMDA tk I. Berikut asal lokasi instansi responden:

Tabel 5.

Lokasi Instansi Responden

\begin{tabular}{|l|r|r|r|}
\hline & $\begin{array}{c}\text { Jumla } \\
\text { h }\end{array}$ & Persentase & $\begin{array}{c}\text { kumulatif } \\
\text { Persentase }\end{array}$ \\
\hline Valid & 10 & 15,6 & 15,6 \\
& 16 & 25,0 & 40,6 \\
Kota Yogya & 10 & 15,6 & 56,3 \\
Kab Sleman & 10 & 15,6 & 71,9 \\
Kab Bantul & 9 & 14,1 & 85,9 \\
Kab Gunungkidul & 9 & 14,1 & 100,0 \\
Kab Kulonprogo & 64 & 100,0 & \\
Total & &
\end{tabular}

Berdasarkan lokasi instansi, maka semua lokasi PEMDA di DIY sudah terwakili dalam penelitian ini, meskipun instansi di wilayah kota merupakan jumlah terbanyak, namun daerah dapat dikatakan berpartisipasi dalam penelitian ini. Sehingga hasil kuesioner diharapkan mewakili semua wilayah PEMDA.

Data dalam penelitian ini berupa data jawaban responden atas pertanyaan dalam kuesioner yang disebarkan. Deskirpsi data dijelaskan berikut ini:

Tabel 6. 


\begin{tabular}{|l|r|r|r|r|r|}
\hline & $\mathrm{N}$ & Minimum & Maximum & \multicolumn{1}{c|}{ Mean } & \multicolumn{1}{c|}{$\begin{array}{c}\text { Std. } \\
\text { Deviation }\end{array}$} \\
\hline $\begin{array}{l}\text { Variabel Perceived } \\
\text { ease of Use (PEU) } \\
\text { Var Perceived Of }\end{array}$ & 64 & 3,000 & 5,000 & 4,12031 &, 610961 \\
$\begin{array}{l}\text { Usefullness (POU) } \\
\text { Var Penerimaan }\end{array}$ & 64 & 2,670 & 5,000 & 4,11531 &, 718738 \\
Valid N (listwise) & 64 & 2,330 & 5,000 & 3,77000 &, 674887 \\
\hline
\end{tabular}

Data dalam penelitian ini diperoleh dengan menyebarkan kuesioner yang berisi pernyataan-pernyataan yang merupakan proksi dari variabel yang diteliti. Jawaban responden diukur dengan skala likert $1-5$. Dimana angka 1 menunjukkan ketidaksetujuan responden atas pernyataan yang diajukan, dan angka 5 menunjukkan persetujuan responden atas pernyataan yang diajukan.

Variabel Perceived Ease of Use (PEU) atau persepsi tentang kemudahan penggunaan SIPKD diukur dengan 7 pertanyaan. Berdasarkan tabel 5.5. nilai minimum untuk variabel Perceived ease of use sebesar 3, yang berarti responden memberikan jawaban paling rendah angka 3 , angka 3 merupakan jawaban netral.tidak tahu. Nilai maksimum sebesar 5, yang berarti responden menyatakan sangat setuju terhadap pernyataan yang diajukan. Nilai rata-rata variabel perceived ease of use (PEU) sebesar 4,1, yang berarti rata-rata responden menyatakan setuju terhadap pernyataan yang diajukan. Setuju dalam hal ini dapat diartikan bahwa responden mempunyai persepsi bahwa SIPKD mudah digunakan dalam pekerjaan mereka.

Variabel Perceived Of Usefullness (POU)atau persepsi tentang kemanfaatan SIPKD dalam pekerjaan diukur dengan 6 pertanyaan. Berdasarkan tabel 5.5 nilai minimum jawaban responden untuk variabel Perceived of Usefullness sebesar 3, yang berarti responden memberikan jawaban paling rendah 3, angka 3 merupakan jawaban netral.tidak tahu. Nilai maksimum sebesar 5, yang berarti responden menyatakan sangat setuju terhadap pernyataan yang diajukan. Rata-rata nilai variabel POU sebesar 4,1 yang berarti rata-rata responden menyatakan setuju terhadap pernyataan yang diajukan. Setuju dalam hal ini dapat diartikan bahwa responden mempunyai persepsi bahwa SIPKD memberi manfaat dalam pekerjaan mereka.

Variabel Penerimaan (Use of SIPKD) diukur dengan 3 pertanyaan. Berdasarkan tabel 5.5 nilai minimum jawaban responden untuk variabel Pennerimaan sebesar 2,3, yang berarti responden memberikan jawaban paling rendah 2, angka 2 merupakan jawaban tidak setuju untuk pernyataan yang diajukan. Nilai maksimum sebesar 5, yang berarti responden menyatakan sangat setuju terhadap pernyataan yang diajukan. Rata-rata nilai variabel Penerimaan sebesar 3,7 yang berarti rata-rata responden menyatakan setuju terhadap pernyataan yang diajukan. Setuju dalam hal ini dapat diartikan bahwa responden mempunyai persepsi bahwa mereka bisa menerima SIPKD dalam pekerjaan mereka. Hal ini sesuai dengan realitasnya karena memang peraturan pemerintah memerintahkan penggunaan keuangan dicatat menggunakan SIPKD. 
Hipotesis yang diajukan dalam penelitian ini diuji menggunanakan uji $F$ dan uji † serta uji koefisien determinasi. Hasil uji masing-masing dijelaskan berikut ini.

\section{Hasil Uji F}

Uji F digunakan untuk menguji apakah variabel independen secara serentak mempengaruhi variabel dependen. Dalam hal ini untuk mengetahui apakah variabel Perceived Ease of Use (PEU) dan Perceived of Usefullness (POU) mempengaruhi penerimaan SIPKD. Hasil uji F ditunjukkan dalam tabel berikut ini:

Tabel 7.

Hasil Uji F

\begin{tabular}{|c|c|c|c|c|c|c|}
\hline \multicolumn{2}{|c|}{ Model } & $\begin{array}{l}\text { Sum of } \\
\text { Squares }\end{array}$ & $d f$ & $\begin{array}{l}\text { Mean } \\
\text { Square }\end{array}$ & $\mathrm{F}$ & Sig. \\
\hline \multirow[t]{3}{*}{1} & Regression & 18,253 & 2 & 9,127 & 53,318 &, $000^{\circ}$ \\
\hline & Residual & 10,442 & 61 & 171 & & \\
\hline & Total & 28,695 & 63 & & & \\
\hline
\end{tabular}

a. Predictors: (Constant), Var POU, Variabel Perceived of Usefullness

b. Dependent Variable: Var Penerimaan

Tabel 5.10 menunjukkan bahwa nilai $F$ sebesar 53,318 dengan tingkat signifikansi 0,000. Hal ini menunjukkan bahwa secara serentak variabel PEU dan POU mempengaruhi penggunaan SIPKD, dalam arti apabila user mempunyai persepsi bahwa SIPKD mudah digunakan dan bermanfaat maka user dapat menerima SIPKD dan diharapkan termotivasi untuk mempelajari dan menggunakan SIPKD.

Uji t digunakan untuk mengetahui pengaruh masing-masing variabel independen (PEU dan POU) terhadap penerimaan SIPKD. Hasil uji t ditunjukkan dalam tabel berikut ini:

Tabel 8.

Hasil Uji $\dagger$

\begin{tabular}{|c|c|c|c|c|c|c|}
\hline \multirow{2}{*}{\multicolumn{2}{|c|}{ Model }} & \multicolumn{2}{|c|}{$\begin{array}{c}\text { Unstandardized } \\
\text { Coefficients }\end{array}$} & \multirow{2}{*}{$\begin{array}{c}\text { Standardized } \\
\text { Coefficients } \\
\text { Beta }\end{array}$} & \multirow[b]{2}{*}{$\mathrm{T}$} & \multirow[b]{2}{*}{ Sig. } \\
\hline & & $B$ & Std. Error & & & \\
\hline \multirow[t]{3}{*}{1} & (Constant) & , 146 &, 356 & &, 409 & 684 \\
\hline & $\begin{array}{l}\text { Variabel } \\
\text { Perceived of } \\
\text { Usefullness }\end{array}$ & ,714 &, 149 & ,646 & 4,796 &, 000 \\
\hline & Var POU & 166 & 127 & 177 & 1,313 & 194 \\
\hline
\end{tabular}

a. Dependent Variable: Var Penerimaan

Tabel menunjukan bahwa hasil uji † adalah sebagai berikut:

a. Nilai † untuk variabel PEU sebesar 4,796 dengan tingkat signifikansi 0,000 , karena nilai sig dibawah 0,05 maka berarti bahwa secara individual variabel PEU mempengaruhi penerimaan SIPKD. Dalam arti apabila user mempunyai persepsi bahwa SIPKD itu mudah dugunakan maka akan semakin mudah user menerima SIPKD. Dengan demikian dapat dikatakan bahwa PEU mempengaruhi penerimaan SIPKD oleh user. 
b. Nilai t untuk variabel POU sebesar 1,313 dengan tingkat signifikansi 0,194 , karena nilai sig diatas 0,05 maka berarti secara individual variabel POU tidak mempengaruhi penerimaan SIPKD. Jadi meskipun user mengetahui bahwa SIPKD bermanfaat dalam pekerjaan mereka namun hal itu tidak mempengaruhi penerimaan user terhadap SIPKD.

Uji Koefisien determinasi digunakan untuk mengetahui seberapa besar variabel independen mampu menjelaskan variabel dependen. Koefisien determinasi ditunjukkan dengan nilai $R^{2}$ ( $R$ square). Hasil uji koefisien dterminasi disajikan dalam tabel berikut ini:

Tabel 9.

Hasil Uji Koefisien Determinasi

\begin{tabular}{|l|c|c|c|c|c|}
\hline Model & $R$ & R Square & $\begin{array}{c}\text { Adjusted R } \\
\text { Square }\end{array}$ & $\begin{array}{c}\text { Std. Error of } \\
\text { the Estimate }\end{array}$ & $\begin{array}{c}\text { Durbin- } \\
\text { Watson }\end{array}$ \\
\hline 1 &, $798^{a}$ &, 636 &, 624 &, 413732 & 2,432 \\
\hline
\end{tabular}

Tabel 5.12 menunjukan bahwa nilai R2 sebesar 0,624. Hal ini berarti bahwa variabel independen (PEU dan POU) mampu menjelaskan $62,4 \%$ perubahan yang terjadi pada variabel penerimaan SIPKD. Dalam arti perubahan yang terjadi pada derajat penerimaan SIPKD mampu diprediksi $62,4 \%$ oleh PEU dan POU. Nilai itu menunjukkan lebih dari $50 \%$ perubahan dalam variabel penerimaan mampu diprediksi oleh variabel PEU dan POU, sehingga hanya kurang dari $40 \%$ perubahan yang tidak bisa dijelaskan oleh variabel PEU dan POU.

Ada tiga hipotesis yang diajukan dalam penelitian ini, dan ketiganya akan dibahas sebagai berikut:

Hipotesis pertama menyatakan bahwa Persepsi Kemudahan Penggunaan/Perceived Ease of Use (PEU) mempengaruhi penerimaan SIPKD. Hasil olah data menunjukkan bahwa nilai $\dagger$ untuk variabel PEU sebesar 4,796 dengan tingkat signifikansi 0,000. Hal ini berarti secara statistik terbukti bahwa PEU mempengaruhi penerimaan SIPKD. Dengan demikian hipotesis pertama yang diajukan, yaitu PEU mempengaruhi penerimaan SIPKD dapat diterima. Implikasi dari hal tersebut adalah, apabila user atau operator SIPKD mempunyai persepsi bahwa SIPKD mudah digunakan maka dia akan menerima SIPKD dengan lebih mudah dan nyaman, yang pada akhirnya user akan menikmati tugasnya sebagai operator SIPKD. Berdasarkan hasil penelitian ini, pengambil kebijakan dapat menarik suatu kebijakan bahwa perancangan sistem atau software bagi PNS, hendaknya memperhatikan faktor kemudahan dalam penggunaan sistem atau teknologi informasi. Ini karena user atau operator sistem informasi akan mudah menerima software apabila user merasa bahwa software tersebut mudah digunakan.

Hipotesis kedua yang diajukan adalah persepsi kemanfaatan (Perceived of usefullness/POU) mempengaruhi penerimaan SIPKD. Hasil analisis statistik menunjukkan bahwa nilai $\dagger$ untuk variabel POU sebesar 1,313 dengan tingkat signifikansi 0,194. Hal tersebut menunjukkan bahwa variabel POU secara statistik tidak mempengaruhi penerimaan SIPKD. Dengan demikian hipotesis kedua yang diajukan dalam penelitian ini tidak dapat diterima. Implikasi atas hasil penelitia ini adalah kemanfaatan SIPKD tidak dijadikan alasan oleh user untuk meenrima SIPKD. Dengan demikian user dalam penelitian ini beranggapan bahwa SIPKD dapat diterima karena SIPKD mudah digunakan, dan bukan karena SIPKD memberikan 
banyak manfaat dalam pekerjaan mereka. Bagi pengambil kebijakan sistem informasi, hasil penelitian ini menunjukkan bahwa user menerima SIPKD bukan karena manfaatnya tetapi karena kemudahannya. Sehingga programmer selanjutnya dapat merancang sistem yang mudah digunakan user, tidak hanya yang bermanfaat bagi atasan.

Hipotesis ketiga yang diajukan adalah PEU dan POU secara bersama-sama (simultan) mempengaruhi penerimaan SIPKD. Hasil uji $F$ menunjukkan bahwa nilai $F$ sebesar 53,318 dengan tingkat signifikansi 0,000. Yang berarti secara simultan PEU dan POU mempengaruhi penerimaan SIPKD. Apabila user mempunyai persepsi bahwa SIPKD itu mudah digunakan dan sekaligus memberi manfaat dalam pekerjaan mereka, maka user akan mudah menerima SIPKD sebagai bagian dari pekerjaan mereka. Implikasi dari hasil ini adalah bahwa user akan mudah menerima sistem atau software yang menurut mereka memang mudah digunakan dan juga memberi manfaat dalam pekerjaan. Implikasi bagi pengambil kebijakan di bidang sistem informasi dan para programmer adalah, dalam merancang software, persepsi user dijadikan dasar perrtimbangan menentukan format software yang akan dirancang. Dengan demikian apabila persepsi atau pendapat user menjadi bahan pertimbangan dalam menentukan format software, diharapkan software yang dihasilkan dapat lebih mudah diaplikasikan dan dijalankan oleh user.

Kesimpulan dari hasil penelitian ini adalah

1. Penerimaan SIPKD di instansi pemerintah di wilayah Yogyakarta dipengaruhi oleh persepsi pemakai terhadap kemudahan penggunaan sistem. Dalam hal ini PNS di wlayah Yogyakarta mempunyai persepsi bahwa SIPKD meudah digunakan sehingga mereka bisa menerima SIPKD dalam pekerjaan mereka,

2. Penerimaan SIPKD di instansi pemerintah di Wilayah Yogyakarta tidak dipengaruhi oleh persepsi kemanfaatan sisten. Dalam hal ini persepsi user mengenai kemafaatan SIPKD tidak akan mempengeruhi penerimaan SIPKD.

3. Secara simultan persepsi kemudahan penggunaan (PEU) dan persepsi kemanfaatan (POU) mempengaruhi penerimaan SIPKD. Dalam hal ini user SIPKD akan lebih mudah menerima SIPKD apabila mereka merasa bahwa SIPKD mudah digunakan dan mempunyai manfaat dalam pekerjaan mereka.

\section{Implikasi dan Keterbatasan}

Hasil penelitian ini mempunyai implikasi bahwa kesuksesan penerimaan SIPKD tergantung pada persepsi user. Apabila user menganggap bahwa SIPKD mudah digunakan dan bermanfaat maka mereka akan lebih mudah meneriman SIPKD dalam pekerjaan mereka. Bagi pengambil keputusan mengenai penggunaan sistem informasi di lembaga pemerintahan, dengan hasil penelitian ini disarankan untuk melakukan uji coba dan pelatihan pada user sebelum sistem secara resmi diterapkan sebagai suatu keharusan. Dengan uji coba dan pelatihan yang terstruktur, maka user akan lebih mudah mengoperasikan sistem informasi.

Penelitian ini hanya dilakukan di Wilayah Yogyakarta, dengan jumlah sampel yang sangat sedikit. Disamping itu karena keterbatasan waktu dan dana, kuesioner tidak dapat menjangkau wilayah kecamatan di pelosok. Sehingga dapat dikatakan bahwa hasil penelitian ini hanya merupakan pendapat dari user SIPKD yang ada di daerah perkotaan. 
Meskipun responden berasal dari 5 wilayah di DIY, namun belum semua Satuan Kerja Perangkat Daerah sebagai user SIPKD, diikutsertakan sebagai responden.

Penelitian berikutnya, diharapkan penelitian fokus pada satu kabupaten atau kota namun melibatkan semua SKPD pengguna SIPKD. Dengan demikian ada kemungkinan perbedaan hasil penelitian antara satu daerah dengn daerah lain, sehingga dalam kaitannya dengan penerapan sistem informasi, dapat digunakan perlakuan yang berbeda antar daerah.

\section{DAFTAR PUSTAKA}

Achjari, Didi. 2012. UGM Menuju Pengelolaan Keuangan Badan Layanan UmUm(PK BLU). Makalah disajikan dalam Rapat Kerja Fakultas Kedokteran Universitas Gadjah Mada, Salatiga, 28 Januari 2012.

Ajzen, I. dan M. Fishbein. 1980. Understanding Attitudes and Predicting Sosial Behavior. Prentice-Hall, Englewood Cliffs, NJ.

Anonim. 2009. Sistem Informasi Keuangan (Modul proses Pencairan UMK). Yogyakarta: Direktorat Keuangan Universitas Gadjah Mada.

Davis, Fred D. 1989. Perceived Usefulness, Perceived Ease of Use, dan User Acceptance of Information Technology. Dalam MIS Quarterly, September, Vol. 13 Issue 3 p. 318-340.

Dewi, Desintia, 2012, Model Penerimaan SIMKEU di UGM dengan Pendekatan Theory Acceptance Model, Skripsi, FITB UTY.

Fernanda, Desi. 2011. Paradigma New Public Management (NPM) Sebagai Kerangka Reformasi Birokrasi Menuju Kepemerintahan Yang Baik (Good Governance) di Indonesia

Ghozali, I. 2005. Aplikasi Analisis Multivariate Dengan Program SPSS. Semarang: Badan Penerbitan Universitas Diponegoro.

Jogiyanto. 2003. Sistem Teknologi Informasi. Yogyakarta: Penerbit Andi.

Jogiyanto. 2007. Sistem Informasi Keperilakuan. Yogyakarta: Penerbit Andi

Kartika, Shinta Eka. 2009. Analisis Proses Penerimaan Sistem Informasi iCons dengan Menggunakan Techonology Acceptance Model pada Karyawan PT. Bank Negara Indonesia (Persero) Tbk di Kota Semarang. Program Studi Magister Manajemen. Universitas Diponegoro.

Muntianah, 2012, Pengaruh Minat Perilaku terhadap Actual Use Teknologi Informasi dengan Pendekatan Teory Acceptance Model, Profit, Vol. 6, No. 1.

Sanjaya, IPS. (2005). Pengaruh Manfaat dan Kemudahan Pada Minat Berperilaku (behavioral intention) Dalam Penggunaan Internet. Kinerja 9 hal 146-156.

Sanusi, Anwar. 2011 . Metodologi Penelitian Bisnis. Jakarta: Salemba Empat. 